\title{
Outpatient burn management and unnecessary referrals
}

\author{
İsa Sözen, M.D., ${ }^{1}$ Cem Emir Guldogan, M.D., ${ }^{1}$ Kemal Kismet, M.D., ${ }^{2}$ \\ Mehmet Zafer Sabuncuoğlu, M.D., ${ }^{3}$ Ahmet Çınar Yasti, M.D. ${ }^{1,4}$
}

\begin{abstract}
1Department of General Surgery, Burns Treatment Center, Ankara Numune Training and Research Hospital, Ankara; 2Department of General Surgery, Burns Unit, Ankara Training and Research Hospital, Ankara;

${ }^{3}$ Department of General Surgery, Suleyman Demirel University Faculty of Medicine, Isparta;

${ }^{4}$ Department of General Surgery, Hitit University Faculty of Medicine, Corum
\end{abstract}

\begin{abstract}
BACKGROUND: This study aimed to determine the profile of burn patients presented in our polyclinic and evaluate the current status in comparison to the treatment methods of past series.

METHODS: Burn patients presented in the polyclinic in a one-year period were included into this prospective study. The records of all patients were examined in respect of gender, age, burn percentage, burn location, cause of burn, degree of burn, dressing material, number of dressings, type of treatment, place of trauma, and month of trauma.
\end{abstract}

RESULTS: From a total of one thousand seven hundred and ninety-five patients presented, management was completed in the polyclinic for one thousand five hundred and eleven cases with a mean age of 27.9 years, with a female: male ratio of 0.88 . While most patients were in the 18-64 age group, hot liquid burn was the leading cause in all age groups $(p<0.05, p<0.00 \mathrm{I})$. Of the total patients, $89.6 \%$ were injured at home $(p<0.00 \mathrm{I})$. The extremities were determined as the body area most often burned $(p<0.00 \mathrm{I})$. While a single dressing was applied to 446 patients $(29.5 \%)$, in $64.9 \%$ of cases polyclinic follow-up was terminated after the first 3 dressings. The mean number of dressings was greater in patients with deep dermal burns (mean 14.5, median I4, $\mathrm{p}<0.00 \mathrm{I}$ ).

CONCLUSION: A higher incidence of burns was found due to increasing urban populations compared to previous years. Currently, the majority of patients are referred to a healthcare facilty near their residences for follow-up after a few dressings. Unneccessary presentation at specialist centres increases the workload of these centres and creates a burden of wasted time and transport expense for the patients. The application of current burn treatment principles in primary and secondary health facilities will reduce the workload of reference centres.

Key words: Burn; management; outpatient; referral.

\section{INTRODUCTION}

Burn injury is a significant health problem caused by the effect of heat, electricity and chemical substances, resulting in damages of different depths and extent. By surrounding almost all body, these damages may spread to the epidermis and dermis layers, the most important protection against physical external effects, and in some cases damage to subcutaneous layers,

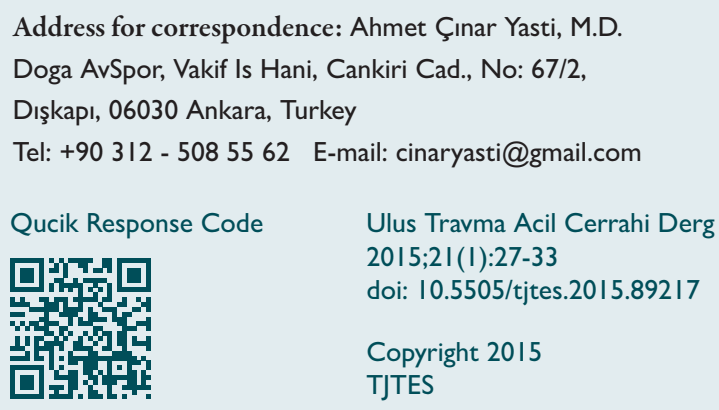

muscle, and bones can be observed. Burns are not localised events affecting only the skin, but a very comprehensive trauma affecting the whole organism and the systemic physiopathological effects define the clinical course and prognosis.

Burn is an injury which may be often encountered by an individual and seen in the general population. Diagnosis and treatment principles of burns are quite different from those of other injuries. Treatment choices may vary from dressings of superficial skin lesions with conventional approaches to surgical intervention. In addition, it is an injury with different effects in the acute and chronic stages which can affect the whole life of the patient and their family. Burns may have a physical and psychological effect on healthcare personnel having a role in the treatment just as much on the patient and their family. Therefore, the teams working in this area need special training and experience. ${ }^{[1]}$

In burn injuiries, the majority of which occur as a result of ac- 
cidents or neglect, the most important factors affecting mortality are the patient's age, the surface area, and depth of the burn. ${ }^{[2]}$ In inhalation burns, the severity is increased more. Determination of the degree of the burn depth is generally made clinically and with physical examination. In the acute phase, a burn, as a dynamic injury, may continue to deepen in the first seventy-two hours. ${ }^{[3]}$ In the determination of total body surface area burnt, rule of nines is widely used. For burn patients, treatment should be planned specifically for burns after any emergency trauma intervention has been made. The success of shock treatment, early eschar excision and early grafting, appropriate and timely use of antibiotics to combat infection, new dressing materials and some new closure methods are positive developments providing good results in burn treatment. ${ }^{[4]}$ In addition to all these characteristics, vast majority of burns are suitable for treatment and follow-up in polyclinic conditions. ${ }^{[5]}$ As has been reported in various series, the majority of burns constitute less than $5 \%$ of total body surface area. The superficial nature of these burns makes it possible for the patients to be treated as outpatients. ${ }^{[5]}$

Until recently, burn facilities and healthcare personnel dealing with burns experienced difficulties since low number of units in operation were uncoordinated and lacked current treatment modalities. One of these problems was the unnecessary transfer of patients. In order to highlight this subject, the correct application of the criteria for the referral of polyclinic patients was clarified in a study published in $2002 .{ }^{[6]}$ In addition to burn units and rooms established in intervening years, ${ }^{[7]}$ the Directive on Action and Establishment of Burn Treatment Units in Healthcare Facilities with Beds was published in $2010^{[8]}$ and in the following years, burn treatment algorithm was published in 2012. ${ }^{[9]}$ This prospective study was planned with the aim of evaluating polyclinic demographics and referrals of an experienced burn unit centre and summarising the treatments made.

\section{MATERIALS AND METHODS}

This prospective study comprised all patients presented at the Burn Treatment Centre polyclinic of our hospital between I January 20I3 and 3I December 20I3. These patients were followed up with prepared forms additional to the hospital records. Patients admitted to the Emergency Department and transferred directly to the clinic from other units by ambulance were excluded from the study.

The centre has a total of twelve beds consisting six intensive care, one isolation, two adult isolation, and three paediatric beds in the hospital located in the city centre. There is an operating theatre and a dressings room in the burn clinic and a polyclinic where outpatients are followed up. The burn clinic is approved by the Ministry of Health of Turkey as a reference hospital and has the role of a training centre giving burn training and providing many specialist doctors and nurses with current information and treatment modalities.
In the current study, a record was made from the patients presented in the polyclinic including age, burn agents, number of dressings applied, choice of treatment applied (conventional/sophisticated wound care products), rate of admittance or outpatient follow-up, hypertrophic scarring, keloid formation, and contracture development. The admittance criteria published by the Turkish Ministry of Health Burn Scientific Committee were taken as the basis for differentiating outpatient or admittance indications of the patients (Table I). ${ }^{[9]}$

The Chi-square test was used in data analysis and the Student's t-test and Anova in the comparison of group mean values. A value of $p<0.05$ was accepted statistically significant.

\section{RESULTS}

In the period of the study, one thousand seven hundred and ninety-five patients presented in the polyclinic. The patients constituted eight hundred and fifty-four (47.6\%) females and nine hundred and forty-one (52.4\%) males, with a mean age of $28.63 \pm 20.03$ years (range, I month-90 years) and median 28.0 years. The mean total burnt surface area (TBSA) was found to be $3.24 \% \pm 4.26 \%$ with a median value of $2 \%$.

Of the patients, two hundred and eighty-four (15.8\%) were hospitalized for treatment. The hospitalized patients included $51.4 \%$ (146) females and $48.6 \%$ (138) males with a mean age of $32.55 \pm 21.96$ years (range, 3 months -90 years), median age 31 years and a mean TBSA of $5.48 \% \pm 5.56 \%$ (range, I \%-69\%). The reason of admittance for treatment was that $47.5 \%$ (135/284) had second degree depth, of which $66 \%$ were deep dermal burns. As $32.4 \%$ (92/284) of the patients had superficial second degree burns, ninety-five patients were admitted due to superficial dermal burns. In the study period, $53 \%$ (284/535) of the patients admitted to the clinic comprised

Table I. Patients requiring hospitalization for treatment

At all ages, TBSA $<20 \%$ 2nd and 3rd degree burns

At all ages, TBSA $\geq \% 5-10$, 3rd degree burns

Ages $<10$ and $>50$, TBSA $\geq \% 10$, 2nd and 3rd degree burns

Face, ear, hand and foot burns

Major joint burns

Genital and perineal burns

Chemical burns

Electric burns

Lightening

Inhalation injuries

Concomitant multitrauma

Presence of co-morbidities

Pregnancy

Child abuse or suspicion 
patients admitted from the polyclinic. The other $47 \%$ of the patients admitted for treatment were those referred directly from external centres and accepted at the clinic or those presented at the emergency department and were seen to be requiring hospitalization.

Of the total one thousand five hundred and eleven patients presented as outpatients in the polyclinic and treated as outpatients, $46.9 \%$ were female with a female: male ratio of 0.88 and a mean age of 27.90 years (range, 10 months- 86 years) with a median age of 27 years. Mean TBSA was found to be $2.82 \% \pm 3.83 \%$ (range, $1 \%-29 \%$ ) with a median value of $1.5 \%$. A significantly greater group of the patients were determined to be in the 18-64 years age group $(p<0.05)$ (Table 2$)$. The most frequently seen burn agent was hot liquid burn at $69.3 \%$ $(1047 / 151 I)$ and hot liquid burns were the most frequently seen burn agents in all age groups $(p<0.001)$ (Table 2$)$. A significantly higher rate of electric burns and chemical burns were observed in the adult age group (Table 2).

Of three adult patients recommended for admittance but refused, one was foreign without a health insurance and the other two absolutely refused any surgery and inpatient treatment, and therefore, were followed up as outpatients.

In comparison with other areas of the body, the upper and lower extremities were found to be the areas most often burned $(p<0.00 \mathrm{I})$ (Table 2$)$.

In the examination of burn depths, majority of the patients followed up in the polyclinic were found to have second degree superficial burns $(p<0.00 I)$ (Table 2$)$.

Table 2. The etiology of the burns of patients treated as outpatients

\begin{tabular}{|c|c|c|c|c|c|c|c|c|c|}
\hline & \multicolumn{8}{|c|}{ Age groups } & \multirow[t]{3}{*}{ Total } \\
\hline & \multicolumn{2}{|c|}{$0-6$} & \multicolumn{2}{|c|}{$7-17$} & \multicolumn{2}{|c|}{$18-64$} & \multicolumn{2}{|c|}{$65+$} & \\
\hline & $\mathbf{n}$ & $\%$ & $\mathbf{n}$ & $\%$ & $\mathbf{n}$ & $\%$ & $\mathbf{n}$ & $\%$ & \\
\hline \multicolumn{10}{|l|}{ Burns cause } \\
\hline Hot liquid & 267 & 25.5 & 104 & 9.9 & 642 & 61.3 & 34 & 3.2 & $1047^{*}$ \\
\hline Fire & 8 & 5.1 & 24 & 15.2 & 120 & 75.9 & 6 & 3.8 & 158 \\
\hline Electric & I & 2.8 & 2 & 5.6 & $33^{+}$ & 91.7 & 0 & 0.0 & 36 \\
\hline Chemical & 4 & 3.9 & 6 & 5.8 & $92^{+}$ & 89.3 & 1 & 1.0 & 103 \\
\hline Contact & 55 & 39.6 & II & 7.9 & 59 & 42.4 & 14 & 10.1 & 139 \\
\hline Others & 0 & 0.0 & 2 & 7.1 & 26 & 92.9 & 0 & 0.0 & 28 \\
\hline \multicolumn{10}{|l|}{ Burned area } \\
\hline Head and neck & 47 & 25.0 & 21 & 11.2 & 118 & 62.8 & 2 & I.I & 188 \\
\hline Upper extremity & 132 & 20.5 & 42 & 6.5 & 453 & 70.3 & 17 & 2.6 & $644^{*}$ \\
\hline Anterior trunk & 24 & 29.6 & 7 & 8.6 & 47 & 58.0 & 3 & 3.7 & 81 \\
\hline Posterior trunk & 8 & 20.0 & 7 & 17.5 & 23 & 57.5 & 2 & 5.0 & 40 \\
\hline Lower extremity & 124 & 23.2 & 71 & 13.3 & 309 & 57.9 & 30 & 5.6 & $534^{*}$ \\
\hline Others & 0 & 0.0 & 1 & 4.2 & 22 & 91.7 & 1 & 4.2 & 24 \\
\hline \multicolumn{10}{|l|}{ Burn depth } \\
\hline First degree & 31 & 15.7 & 18 & 9.1 & 144 & 73.1 & 4 & 2.0 & 197 \\
\hline Superficial second degree & 301 & 23.7 & 129 & 10.1 & $800^{*}$ & 62.9 & 42 & 3.3 & $1272^{*}$ \\
\hline Deep second degree & 3 & 7.7 & 2 & 5.1 & 25 & 64.1 & 9 & 23.1 & 39 \\
\hline Third degree & 0 & 0 & 0 & 0 & 1 & 100.0 & 0 & 0 & 1 \\
\hline Fourth degree & 0 & 0 & 0 & 0 & 2 & 100.0 & 0 & 0 & 2 \\
\hline \multicolumn{10}{|l|}{ Place of burns } \\
\hline Home & 331 & 24.4 & 136 & 10.0 & 834 & 61.6 & 53 & 3.9 & 1354 \\
\hline Office & 3 & 2.6 & 10 & 8.8 & 100 & 87.7 & 1 & 0.9 & 114 \\
\hline Out door & I & 3.4 & 3 & 10.3 & 25 & 86.2 & 0 & 0 & 29 \\
\hline Others & 0 & 0 & 0 & 0 & 13 & 92.9 & 1 & 7.1 & 14 \\
\hline Total & 335 & 22.2 & 149 & 9.9 & +972 & 64.3 & 55 & 3.6 & 1511 \\
\hline
\end{tabular}

${ }_{p}<0.001 ;+p<0.05$ 
Table 3. A comparison of the number of dressings of outpatients with second degree superficial and deep burns

\begin{tabular}{lccc}
\hline & & Burn depth & All group \\
\cline { 2 - 4 } & Superficial & Deep & 1311 \\
\hline Patient number & 1272 & 39 & $3.73 \pm 3.16$ \\
Mean \pm Standard deviation & $3.40 \pm 2.52$ & $14.51 \pm 2.89$ & 2.91 \\
Median & 2.83 & 14.50 & $1-21$ \\
Range & $1-17$ & $9-21$ & 4893 \\
Number of dressings & 4327 & 566 &
\end{tabular}

Table 4. Patients to whom wound care products were applied apart from conventional treatments

\begin{tabular}{|c|c|c|c|c|c|c|c|c|c|}
\hline & \multicolumn{8}{|c|}{ Age } & \multirow[b]{3}{*}{$\mathbf{n}$} \\
\hline & \multicolumn{2}{|c|}{$0-6$} & \multicolumn{2}{|c|}{$7-17$} & \multicolumn{2}{|c|}{$18-64$} & \multicolumn{2}{|c|}{$65+$} & \\
\hline & $\mathbf{n}$ & $\%$ & $\mathbf{n}$ & $\%$ & $\mathbf{n}$ & $\%$ & $\mathbf{n}$ & $\%$ & \\
\hline \multicolumn{10}{|l|}{ Dressing type } \\
\hline Conventional & 316 & 21.5 & $|4|$ & 9.6 & 960 & 65.3 & 53 & 3.6 & 1470 \\
\hline Wound care product & 19 & 46.3 & 8 & 19.5 & 12 & 29.3 & 2 & 4.9 & 41 \\
\hline
\end{tabular}

The burn injury was received in the houses in $89.6 \%$ $(1354 / 15 I I)$ of the patients managed in the polyclinic $(p<0.001)$ (Table 2).

Within a year, five thousand two hundred and ninety dressings were applied to one thousand five hundred and eleven patients. Mean number of dressings was $3.49 \pm 3.06$ (range, I-2I) with a median value of 3 . A single dressing was applied to four hundred and forty-six (29.5\%) patients, while polyclinic follow-up was completed with two dressings in two hundred and seventy-one (17.9\%) patients, and three in two hundred and sixty-four (17.5\%) patients (Fig. I). In the evaluation of the number of dressings applied to patients, in the comparison of patients with second degree superficial burns and those presented with second degree deep burns but refused admittance and surgery, the number of dressings applied to the second degree deep burn group patients was found statistically significantly high $(p<0.00 I)$ (Table 3$)$.

Conventional methods were used in the treatment of $97.3 \%$ of the patients and wound care products were used in the treatment of $2.7 \%(4 / / 15 I I)$. Apart from one patient aged over 65 years with deep dermal burns, all wound care products were used on patients with superficial dermal burns (Table 4). While 47.5\% (19/40) of the wound care products used were applied to the $0-6$ years age group, this group comprised $4.5 \%$ (19/422) of the $0-6$ years age patient group.
When the distribution of patients throughout the year was examined according to the seasons, it was determined that the greatest number of patients (152) were treated in July and the fewest (94) in March (Fig. 2). In the evaluation according to age, most burns were observed in the adult age group in July and August in open areas, although no statistically significant grouping was seen.

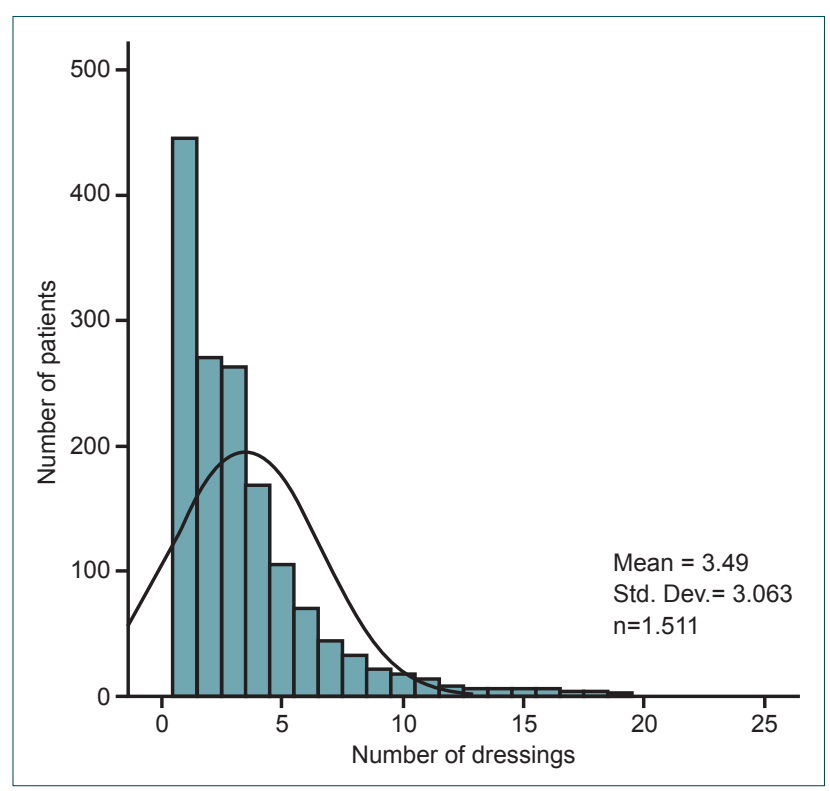

Figure 1. Histogram of the number of dressings applied to patients. 


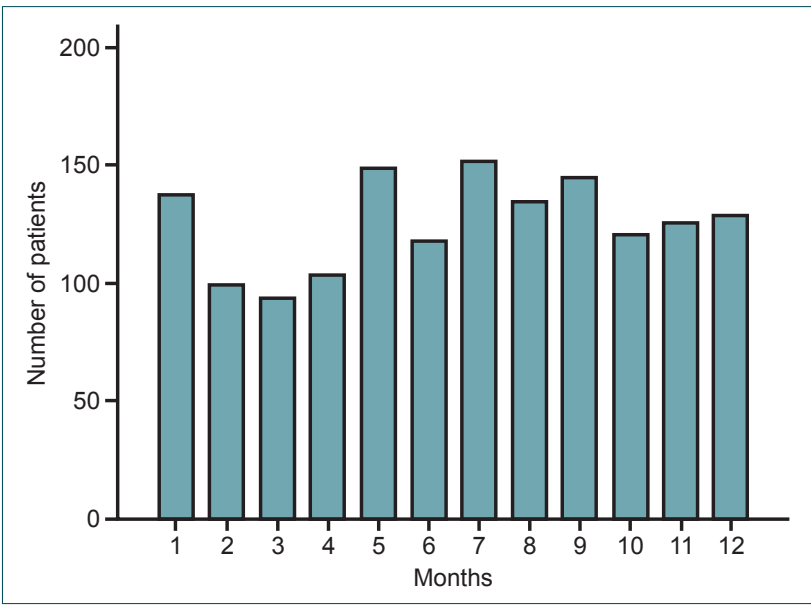

Figure 2. Distribution of patients treated in the polyclinic according to months.

During 2013, no patients presented in the polyclinic for the treatment of contracture developed due to hypertrophic scarring or keloid formation pertaining in comparison to previous years.

\section{DISCUSSION}

In the acute phase of burns, although good results can be obtained with treatment methods accepted as successful in terms of survival, in the long-term, there may be lifelong effects for the patient and their family including changes in color, scatris tissue formation, and loss of organs and functions regarding hypertrophic scarring and keloid. ${ }^{[10]}$

Vast majority of burn injuries are comprised of less than $10 \%$ TBSA. ${ }^{[1,12]}$ Most of this group consists of patients suitable for outpatient treatment and follow-up, not having deep dermal burns and not requiring a sophisticated treatment modality, such as grafting or skin equivalents. ${ }^{[6]}$ Within the study period, vast majority of the patients presented were treated as outpatients (admitted 284, polyclinic 15II). Mean TBSA of the patients treated in the polyclinic was determined to be $2.82 \% \pm 3.83 \%$, parallel to data in the literature. ${ }^{[1,12]}$

A significant majority of the patients treated as outpatients were in the 18-64 years age group. Since there are two paediatric hospitals within $2 \mathrm{~km}$ of our hospital, this may be the reason for the low number of paediatric patients. When the etiology of the burns was examined, significantly more hot liquid burns and flame burns were determined, similar to the findings of previous studies in developed and developing countries. $^{[13-15]}$ Majority of these were in patients hospitalized for treatment. When the rates of patients followed up in the polyclinic were examined, while data from the USA has reported an admittance rate of $3.3 \%$, the rate of the current study was found to be $15.8 \%$. This rate is considered high since in cases of severe burns with indications of admittance, the preference of the patients' families for ambulance units of the emergency healthcare services plays a role in the di- rect presentation at our hospital. Being the reference centre for Turkey, our clinic is the largest centre in Ankara and the surrounding area, and it is the only training unit. The adult age group was observed to experience a significantly greater number of electrical and chemical burns.

In the evaluation of the body areas with burns, although upper and lower extremities were seen significantly more in the current series, no significant difference was observed between the two etiologies.

When the depth of the burns was examined, a significant number of patients were determined to have second degree superficial burns. Deeper burns often requiring surgery were treated in any case by admission as inpatients, with the treatment approach of early excision and grafting accepted in this context. ${ }^{[2,16]}$

During the study period, a total of five thousand two hundred and ninety dressings were applied to the one thousand five hundred and eleven patients treated in the polyclinic. The recommended treatment for superficial burns suitable for polyclinic follow-up is to provide protection from moisture and superficial antibacterial prophylaxis. ${ }^{[1]]}$ In the event of unexpected development of infection in superficial burns, flat paraffin-impregnated leno cloths should be sufficient. When these are not available, ready-prepared, sterile gauze compresses impregnated with $0.2 \%$ nitrofurazone are used as closures. Even though it has been reported that double layer sophisticated industrial products of one layer silicone and the other consisting of various collagens can be used on patients, particularly paediatric patients, ${ }^{[18]}$ as an approach in our clinic, we do not find the use of these products suitable for minor burns on outpatients, as has also been indicated in the literature. ${ }^{[19]}$

In the current series, for patients with superficial burns, it was not deemed appropriate to change dressings more than once every two days when there were no signs of local or systemic infection. When it is ensured that wound healing is within the physiological boundaries, the frequency of dressing changes can be extended to five days. Most patients in the current series were able to complete the polyclinic treatment with necessary recommendations and application of one, two or three dressings. In a previous study in our clinic, it was determined that the majority of burn patients had a low socioeconomic level. ${ }^{[20]}$ In order to reduce the economic and social burden to a minimum, written information and treatment plans were given to the patient or their guardian and they were directed to their nearest healthcare facility for continuation of the treatment.

Mean number of dressings was found to be significantly high in the patient group with deep dermal burns, not accepting surgery or hospitalization. As the median number of dressing changes was found to be 14.5 in this group, it meant that the wound closure took a long time. In the literature, sur- 
gical treatment has been recommended for patients whose wound healing is thought to take a 21 -day period. ${ }^{[21]}$ Of the total one thousand three hundred and eleven patients in the current study with second degree burns, thirty-nine patients had deep burns. In this patient group, the maximum healing period was determined as $2 \mathrm{I}$ days with daily dressing changes. No data of formation of hypertrophic scarring was found in this patient group. In addition, no patient presented at the plastic surgery clinic of our hospital or clinic owing to contracture during the study period. This can be considered to be explained by the provision of appropriate physical exercises and proper application of treatment. In this respect, it would not have been ethical to have planned a randomized prospective study.

When the outpatient numbers of our polyclinic for 2013 were compared with those of 2002, an increase of $169.2 \%$ was seen (15I I/893). ${ }^{[6]}$ For the same period, a $20 \%$ increase was observed in the population of the province of Ankara (4.007.860, 2002; 4.965.384, 2013; data from the Turkish Board of Statistics [TÜiK]).

For $29.6 \%$ of the patients in the current study, a single dressing was sufficient. In a study from the same centre in 2002 , this rate was $38 \%{ }^{[6]}$ Although seen as a decrease in percentage, the number of patients was three hudrend and forty-two compared to the current study number of four hundred and forty-six. This rate, explaining an increase of $30.4 \%$ in the patient group with a single dressing applied, is significant for the period in which the population of Ankara increased $20 \%$. Furthermore, within that period, two burn units and a burn centre and polyclinic for paediatric patients came into service. From 2008, the Burn Scientific Committee established by the Ministry of Health came into operation, prepared a directive, and published the Burn Treatment Algorithm, which has value in the sense of being the first original treatment algorithm in Turkey. ${ }^{[7-9]}$ However, from 2013 onwards, besides the acquisition of current information and treatment approaches by healthcare personnel, the necessity for treatments of simple burn injuries outside third stage healthcare institutions came to the fore. In a study by Lloyd et al. ${ }^{[22]}$ of the American example, majority of burn patients has been observed to be treated by family doctors through postgraduate training and training programmes of discussions at congresses. By this way, a tangible improvement was obtained for both the patient and social security institutions. The close location of a healthcare provider for treatment will obviously be more useful for patients physically, economically, socially, and psychologically.

As our clinic is accepted as a developed, reference unit burn centre, the number of polyclinic patients is much greater. By increasing the number of staff trained in the field of burns, instead of burns of a degree requiring a single dressing, the intensity of our centre will be reduced. Thus, we will have room for patients who truly need treatment in an advanced burn centre. Otherwise, there will be economic loss in addition to the physical and psychological trauma to the patient and their family even when the burn injury is minor.

Of the patients admitted to our clinic, 53\% were from the polyclinic and $47 \%$ were referred for hospitalization. These patients were not only from nearly every region of Turkey but also from neighbouring countries such as Azerbaijan, Iraq, Syria, Afghanistan, Russia, Albania, Libya, Somalia, and Sudan and also from distant countries. The obtained results are positive feedbacks for a reference centre and repeated patient referencing is accepted as a measurement for our clinic accepted as a reference centre. Moreover, our clinic has been accredited as a Burn Training Centre by the Ministry of Health of Turkey.

While $97.3 \%$ of the patients were treated by the above-mentioned conventional methods, wound care products were used on a very small number, showing that the effort and labour input of healthcare personnel are very important in the treatment of burns. That the number of physicians and nurses providing service was the same in 2013 as in 2002 clearly shows the additional workload. The use of wound care products for polyclinic patients would decrease the frequency of dressing changes and increase patient comfort. The real reason for the low use of these products in the polyclinic is that reimbursement is not made by the social security system for this outpatient group of patients.

\section{Conclusion}

The increase in the number of patients determined in the study period reveals that burns are still a serious problem in our country. In comparison with the past, a high number of patients treated with one or two dressings indicates that the treatment of minor burns is not made in primary and secondary healthcare facilities. The treatment of patients with minor burns in close or convenient other healthcare institutions would reduce the workload of centres as well as additional economic and psychological burden on patients and their families and would, thus, save time for all.

\section{Conflict of interest: None declared.}

\section{REFERENCES}

1. Pavoni V, Gianesello L, Paparella L, Buoninsegni LT, Barboni E. Outcome predictors and quality of life of severe burn patients admitted to intensive care unit. Scand J Trauma Resusc Emerg Med 2010;18:24.

2. Wolf SE, Debroy M, Herndon DN. The cornerstones and directions of pediatric burn care. Pediatr Surg Int 1997;12:312-20. CrossRef

3. Youn $\mathrm{YK}, \mathrm{LaLonde} \mathrm{C}$, Demling $\mathrm{R}$. The role of mediators in the response to thermal injury. World J Surg 1992;16:30-6. CrossRef

4. Supple KG. Physiologic response to burn injury. Crit Care Nurs Clin North Am 2004;16:119-26. CrossRef

5. National Burn Repository 2005 report. American Burn Association; 2006:35. 
6. Yastı AÇ, Kama AN. Yanık olgularında gereksiz hasta nakilleri ve sonuçları. Ankara Cerrahi Dergisi 2005;7:75-8.

7. Yasti $\mathrm{AC}, \mathrm{Koc} \mathrm{O}$, Sencan I. Organizing burn patient hospitalisation and transfer at a developing country. World J Surg 2011;35:430.

8. http://www.istanbulsaglik.gov.tr/w/sb/tedk/pdf/yonergeson.pdf.

9. http://www.tkhk.gov.tr/Eklenti/307,23022012-tc-sb-yanik-algoritmasi.pdf?

10. Rossi LA, Braga EC, Barruffini RC, Carvalho EC. Childhood burn injuries: circumstances of occurrences and their prevention in Ribeirão Preto, Brazil. Burns 1998;24:416-9. CrossRef

11. American Burn Association. Burn incidence and treatment in the United States: fact sheet 2011. http://www. ameriburn.org/resources_factsheet. php [cited 25.10.13].

12. Brusselaers N, Monstrey S, Vogelaers D, Hoste E, Blot S. Severe burn injury in Europe: a systematic review of the incidence, etiology, morbidity, and mortality. Crit Care 2010;14:R188. CrossRef

13. Herndon D. Epidemiological, demographic, and outcome characteristics of burn injury. Total burn care (4th ed.). Edinburgh: Saunders; p. 23. ISBN 978-1-4377-2786-9.

14. Asuquo ME, Ekpo R, Ngim O, Agbor C. A prospective study of burn trauma in adults at the university of calabar teaching hospital, calabar (South eastern Nigeria). Eplasty 2008;8:36.
15. Han TH, Kim JH, Yang MS, Han KW, Han SH, Jung JA, et al. A retrospective analysis of 19,157 burns patients: 18-year experience from $\mathrm{Hal}$ lym Burn Center in Seoul, Korea. Burns 2005;31:465-70. CrossRef

16. Senel E, Yasti AC, Reis E, Doganay M, Karacan CD, Kama NA. Effects on mortality of changing trends in the management of burned children in Turkey: eight years' experience. Burns 2009;35:372-7. CrossRef

17. Durtschi MB, Orgain C, Counts GW, Heimbach DM. A prospective study of prophylactic penicillin in acutely burned hospitalized patients. J Trauma 1982;22:11-4. CrossRef

18. Barret JP, Dziewulski P, Ramzy PI, Wolf SE, Desai MH, Herndon DN. Biobrane versus $1 \%$ silver sulfadiazine in second-degree pediatric burns. Plast Reconstr Surg 2000;105:62-5. CrossRef

19. Hartford CE. Care of outpatient burns. In: Herndon DN, editor. Total burn care. 4th ed., 2012. p. 81-92. CrossRef

20. Yasti AC, Tumer AR, Atli M, Tutuncu T, Derinoz A, Kama NA. A clinical forensic scientist in the burns unit: necessity or not? A prospective clinical study. Burns 2006;32:77-82. CrossRef

21. Engrav LH, Heimbach DM, Reus JL, Harnar TJ, Marvin JA. Early excision and grafting vs. nonoperative treatment of burns of indeterminant depth: a randomized prospective study. J Trauma 1983;23:1001-4. CrossRef

22. Lloyd EC, Rodgers BC, Michener M, Williams MS. Outpatient burns: prevention and care. Am Fam Physician 2012;85:25-32.

\section{KLINIIK ÇALIŞMA - ÖZET}

\section{Yanık hastalarının ayaktan takibi ve gereksiz hasta nakilleri}

\section{Dr. İsa Sözen, ${ }^{1}$ Dr. Cem Emir Guldogan, ${ }^{1}$ Dr. Kemal Kismet, ${ }^{2}$ Dr. Mehmet Zafer Sabuncuoğlu, ${ }^{3}$ Dr. Ahmet Çınar Yasti ${ }^{1,4}$}

${ }^{1}$ Ankara Numune Eğitim ve Araştırma Hastanesi, Genel Cerrahi Kliniği, Yanık Tedavi Merkezi, Ankara;

${ }^{2}$ Ankara Eğitim ve Araştırma Hastanesi, Genel Cerrahi Kliniği, Yanık Ünitesi, Ankara;

${ }^{3}$ Süleyman Demirel Üniversitesi Tıp Fakültesi, Genel Cerrahi Anabilim Dalı, Isparta;

${ }^{4}$ Hitit Üniversitesi Tıp Fakültesi, Genel Cerrahi Anabilim Dalı, Çorum

AMAÇ: Polikliniğimize başvuran yanık hasta profilini ortaya koymak ve tedavi yönetimini geçmiş seriler ile karşılaştırarak güncel durumu değerlendirmektir.

GEREÇ VE YÖNTEM: Bir yıl süreyle polikliniğimize başvuran hastalar ileriye yönelik çalışmaya alındı. Tüm hastaların kayıt altına alınan cinsiyet, yaş, yanık yüzdesi, yanık yeri, yanık nedeni, yanık derecesi, pansuman malzemesi, pansuman sayısı, tedavi şekli, olay yeri ve olayın olduğu aya göre dağıımı incelendi.

BULGULAR: Toplam 1795 hastanın yönetimleri poliklinikte tamamlanan I5 I I'inin ortalama yaşı 27.9, kadın/erkek oranı 0.88 olmuştur. Çoğunluğu I8-64 yaş hastalar oluştururken tüm gruplarda sıcak sıvı yanığı ilk sıradaydı $(p<0.05, p<0.00$ I). Hastaların \%89.6'sı evde yaralanmıştı ( $p<0.00$ I). Ekstremiteler diğer bölgelere göre daha sık yanan vücut bölgesiydi ( $p<0.00 \mathrm{I})$. Hastaların 446'sına (\%29.5) tek pansuman uygulanırken \%64.9'u ilk üç pansuman sonrasında hastanemiz poliklinik takipleri sonlandırılmıştır. Derin dermal yanıklı hastalarda ortalama pansuman sayısı daha fazla olmuştur (ortalama I4.5, ortanca I4, $\mathrm{p}<0.001$ ).

TARTIŞMA: Geçmiş yıllar ile yapılan karşılaştırmada il nüfusu artışından daha yüksek yanık insidansı bulunmuştur. Halen hastaların çoğunluğu az sayıda pansuman sonrası takipleri için evlerine yakın sağıı birimlerine yönlendirilmektedir. Mevcut durumda hastaların deneyimli merkezlere gereksiz başvuruları ile bu merkezlerin iş yükünün artıııması yanında hastalara ilave ulaşım yükü ve zaman israfı yaşatılmaktadır. Güncel yanık tedavi prensiplerinin birinci ve ikinci basamakta edinilmesi ile referans merkezin iş yükü azaltılabilecektir.

Anahtar sözcükler: Ayaktan; nakil; yanık; yönetim.

Ulus Travma Acil Cerrahi Derg 20I5;2I(1):27-33 doi: 10.5505/tjtes.2015.89217 